\title{
Nasal Type Extranodal NK/T-Cell Lymphoma
}

National Cancer Institute

\section{Source}

National Cancer Institute. Nasal Type Extranodal NK/T-Cell Lymphoma. NCI Thesaurus. Code C4684.

An aggressive, predominantly extranodal, mature T-cell non-Hodgkin lymphoma. It is characterized by an often angiocentric and ang iodestructive cellular infiltrate composed of EBV positive NK/T cells. The nasal cavity is the most common site of involvement. Patients often present with midfacial destructive lesions (lethal midline granuloma). The disease may disseminate rapidly to various anatomic sites including the gastrointestinal tract, skin, testis, and cervical lymph nodes. It is also known as angiocentric T-cell lymphoma. The term "polymorphic reticulosis" has been widely used to describe the morphologic changes seen in this type of lymphoma. However, the latter term may also apply to lymphomatoid granulomatosis, which is an ang iocentric and ang iodestructive EBV positive B-cell lymphoproliferative disorder. 